\title{
The Agent Orange Controversy in the Republic of South Korea
}

\author{
Alvin L. Young and Kristian L. Young* \\ A. L. Young Consulting, Inc., Cheyenne, Wyoming, United States \\ *Email: Alvin L. Young, youngrisk@aol.com
}

\begin{abstract}
In numerous domestic and international media reports throughout May and June 2011, allegations were made by United States veterans that the military defoliant Agent Orange had been buried in 1978 at Camp Carroll, a US military installation in the Republic of South Korea. Moreover, some US veterans who had served in South Korea in the 1960s and 1970s claimed that Agent Orange had been routinely sprayed in South Korea. Records and publications confirmed that the only use of the tactical herbicides Agents Orange and Blue in Korea occurred in April - July 1968 on the Korean Demilitarized Zone (DMZ). This article is intended to clarify what occurred in 1968, to explain why Agent Orange could not have been buried or sprayed in other locations in Korea, to describe the actual Korean military operation on the DMZ, and to briefly review the supporting science.
\end{abstract}

Keywords: Agent Orange, Korea, tactical herbicides, Korean DMZ, Eighth US Army, Camp Carroll, Agent Blue

\section{$1 \quad$ Introduction}

For four decades, controversy has surrounded the tactical use of herbicides, specifically "Agent Orange", in Southeast Asia by the United States Department of Defense (DOD). The breadth of the controversy has spanned the gamut from alleged military use of chemical weapons, to ecological damage and public health impacts, and to social and political concerns [1]. There continues to be ongoing controversy over the use of Agents Orange and Blue in the Republic of South Korea and the alleged subsequent disposal of the surplus inventories of the tactical herbicides on US military installations in South Korea. In May 2011, three United States (US) veterans told a Phoenix, Arizona television station in the United States that the Eighth United States Army (EUSA) had buried the defoliant Agent Orange at Camp Carroll, Korea in 1978 [2]. As a result of their alleged actions to help bury large amounts of the chemical in a ditch on the installation, they claimed to have suffered health problems from their exposure to Agent Orange. Because of their claims, other US veterans and Korean citizens made new claims that Agent Orange was also buried or spilled at other US military installations and that it was sprayed near villages adjacent to the Korean Demilitarized Zone (DMZ) and elsewhere in Korea [3, 4]. The time span for these later allegations was from 1963 through 1978. In December 2006, the US Department of Defense documented the history of the Department's programs for the testing, evaluation, and storage of tactical herbicides, including Agent Orange, other than their use in South Vietnam [5]. The only documented use of tactical herbicides in Korea occurred in April - July 1968 as part of a program to control vegetation on the Korean Demilitarized Zone and included Agents Orange and Blue [6].

The purpose of this article is to: (1) document the history of the Korean military's use of tactical herbicides in Vietnam and how this provided the justification for their use on the Korean DMZ; (2) document the political, scientific and logistical processes used in selecting, obtaining, and transporting the tactical herbicides for use on the DMZ in 1968; (3) document from DOD records the actual application of the tactical herbicides on the Korean DMZ; (4) document that Agent Orange could not have been buried or sprayed in other locations in Korea; and (5) review the science that concluded that the use of the tactical herbicides on the Korean DMZ resulted in minimal environmental and human impacts. 


\section{$2 \quad$ History of the Korean Military's Use of Tactical Herbicides}

The history of Agent Orange and Korean veterans does not begin with the use of Korean soldiers to spray Agent Orange and Agent Blue on the Korean DMZ, but rather it begins with the use of tactical herbicides as tools to prevent infiltration of Korean base perimeters in the former Republic of Vietnam (South Vietnam) during the Vietnam War. More than 312,800 Korean combat veterans were stationed in South Vietnam's II Corps in the seven years from their arrival in 1965 to their departure in 1971. The motto of the men who served from Korea in South Vietnam was " 7 Years for Peace and Construction" and the accomplishments of the Korean forces in Vietnam were a great sense of pride to the Korean people [7]. It was of great political significance for the Korean government to be able to send its army as an independent force. The major Korean Forces consisted of the Republic of Korea (ROK) Capital Division, ROK $9^{\text {th }}$ Division, and the ROK $2^{\text {nd }}$ Marine Brigade [7]. From their first deployment in II Corps (from Qui Nhon to Phan Rang) until their departure, a major concern was securing the base perimeters so as to maintain a clear field of fire. Of the many methods used to do that task by the Allied forces (including the Korean forces) was the use of the tactical herbicides to control the perimeter vegetation [8]. According to a comprehensive research report on the Vietnam War, Korean Units in Vietnam received tactical herbicides such as Agent Orange, Agent White, and Agent Blue from the US Army Chemical Corps, but the Korean military did not permit the US Army Chemical Corps to conduct the spray operations. That was the duty and responsibility of the Korean forces within their tactical area of responsibility, and they employed their own ground and helicopter equipment to do the applications [9].

Most Korean military units below the division level used tactical herbicides extensively because of their effectiveness in controlling perimeter vegetation [10]. Thus, it was not surprising that the Korean Ministry of National Defense jointly supported with the EUSA a subsequent recommendation for using tactical herbicides on the Korean DMZ in 1968.

\section{Proposed Use of Herbicides on the Korean DMZ}

In the period of 1966 through 1969, United States and South Korean troops fought a series of skirmishes against North Korean soldiers in an undeclared war along the DMZ. Sarantakes has described in detail this "Quiet War" [11]. He noted that the frequency of attacks on South Korean and American troops increased in relationship to the density of the vegetation. Thus, by 1968 Army Engineers from EUSA and the First Republic of Korea Army (FROKA) implemented the use of heavy diesel plows and defoliants to remove much of the shrubbery along the demarcation line, making it harder for enemy troops to hide and conduct ambushes [11]. This was not the first time that herbicides were used to defoliate vegetation on the DMZ. However, 1968 was the first time that "tactical herbicides" were used to defoliate vegetation on the DMZ. Tactical herbicides were herbicides specifically developed and tested to be used in combat military operations, e.g., the use in Vietnam [6]. These tactical herbicides included Agents Orange, White and Blue and were not registered for commercial use, or for routine use on military installations. The only US military units authorized to spray tactical herbicides were the US Army Chemical Corps and the US Air Force Units that comprised Operation RANCH HAND.

In November 1963, EUSA recognized the success of defoliation operations in Vietnam conducted by personnel of Operation RANCH HAND. The Commanding General of the EUSA requested technical assistance from RANCH HAND in determining feasibility of conducting defoliation operations along the DMZ [12]. "If effective, the operation should (a) improve capability of UN Forces to detect and apprehend infiltrators, (b) provide prominent delineation of the southern boundary of the DMZ to insure against accidental overflight by friendly aircraft, and, (c) reduce amount of troop labor required to maintain cleared area immediately south of DMZ" [12]. The Commander of RANCH HAND visited EUSA on 16 November 1963, and provided recommendations to EUSA, but the decision to use tactical herbicides was denied due to the possibility of accusations of armistice violations, and a resulting potential propaganda harvest by the Communist world [6].

Although the use of tactical herbicides was denied, the Chemical Corps of the Republic of Korea VI Corps did apply a small amount of the commercial herbicide (2,4-dichlorophenoxy acetic acid, 2,4-D) in late 1963 in selected areas such as observation posts and guard posts to clear fields of fire [6]. In 1965, 
the $2^{\text {nd }}$ US Infantry Division requested that the use of herbicides be investigated for controlling vegetation within the anti-infiltration barrier on the DMZ [6]. It was noted that commercial herbicides and application equipment were already on hand and capable of use. The request was staffed and again denied due to possible adverse North Korean reactions [6].

In 1966, historical records of the EUSA stated: "Good fields of fire and fields of observation are essential to DMZ Operations. Various methods including chemicals, mechanical devices, and hand labor may be used to clear these fields. Each method is effective, but conditions and locations will dictate which should be employed... Plant growth may be killed at the roots through the application of chemical soil sterilants... "Tests conducted by the US 3d Brigade, 2d Infantry Division favor use of a herbicide called TELVAR MONURON which can be applied by use of the Power-Driven Decontamination Apparatus. Other herbicides were considered either ineffective or creative of undesirable effects outside the area of interest... Tests are planned for spraying the wire with waste oil or diesel oil as a preservative. Results remain to be seen" [13].

Despite the comment on "other herbicides" the commercial herbicide 2,4-D was recommended with the commercial herbicide 3-(p-chlorophenyl)-l,l-dimethylurea (Monuron) for limited vegetation control on the DMZ in 1967. On 20 September 1967, the EUSA issued implementing instructions to the First Republic of Korea Army (FROKA) and the I US Corps to make test applications of Monuron and 2,4-D on flat terrain ( $2^{\text {nd }}$ US Infantry Division) and in the mountains ( $21^{\text {st }}$ ROK Infantry Division). It was decided that despite the lateness of the season (September/October 1967), it was necessary to train personnel and to evaluate spray equipment for any future operation, and to test any reaction from the North Korean government [14, 15].

Early in1967, as part of a general review of the Demilitarized Zone defenses, the United Nations Command (UNC), the United States Forces Korea (USFK), and the Korean Ministry of National Defense found that dense vegetation within the DMZ and contiguous areas continued to provide cover for North Korean infiltration by raiding parties. The vegetation in most areas had grown unencumbered since the Armistice and was an important part of the DMZ defensive problem. In March 1967, representatives of the Plant Sciences Laboratory, US Army Biological Laboratories, Fort Detrick, Maryland visited Korea and inspected typical vegetation growth in selected areas contiguous to the DMZ. Based upon this evaluation, the Plant Sciences Laboratory recommended the use of tactical herbicides, specifically Herbicides Orange and Blue, and the commercially available soil-applied herbicide Monuron (UROX 22) to control general and specific vegetation growth adjacent to the DMZ [15]. This recommendation was jointly supported by the US Department of Defense and the Korean Ministry of National Defense [16].

The decision, however, to use tactical herbicides required obtaining approval of the United States Government, the Republic of South Korea (ROK) Government, and the United Nations Command. Numerous messages were dispatched during the period May through September 1967. Throughout September 1967, the US Secretary of State continued discussion of the program with the Republic of Korea Government. These discussions provided the acceptance of the program by the ROK Prime Minister, and on 20 September 1967 both governments (ROK and US).

Gave permission for the use of the tactical herbicides to be sprayed in the area between the DMZ South tape and the Civilian Control Line, including the "Area Adjacent to the Southern Limit Line". This would total a strip of land that would be roughly 320 meters wide and 240 kilometers long [15].

On 20 January 1968, RADM John V. Smith, Senior Member of the United Nations Command, Military Armistice Commission, disclosed in answer to North Korean charges of chemical warfare, that the UN Command may use defoliants to clear underbrush from fields of fire in the DMZ and thereby reduce Communist infiltration [16].

\section{The Selection of Tactical Herbicides}

Why select tactical herbicides for defoliating the Korean DMZ in 1968 when commercial herbicides were available in 1967? The commercial herbicide 2,4-D and other "phenoxy" herbicides were widely used in Korea. Data from the Korean Yearbook of Agriculture and Forestry Statistics confirmed that in 1967, more than 187 metric tons of phenoxy herbicides, including 2,4-D, had been used in Korean agriculture 
and forestry programs [17]. However, there were four major reasons for selecting Agent Orange and Agent Blue:

- Both the Korean Forces and the United States Forces had extensive experience with using tactical herbicides for vegetation control around base perimeters in South Vietnam, and the mixture of 2,4-D and 2,4,5-trichlorophenoxy acetic acid (2,4,5-T), i.e., Agent Orange, was especially effective against a wide variety of herbaceous weeds and shrubs. Agent Blue (cacodylic acid) was very effective for controlling rapidly growing grasses, i.e., elephant grass, that also characterized the vegetation growing adjacent to base perimeters [18];

- The two tactical herbicides were readily available in South Vietnam in 1968. In FY 1968 (1October 1967 - 30 September 1968), the United States Air Force Logistic Command delivered more than 178,000 drums (each 208 liters) of tactical herbicide to South Vietnam. Tactical herbicides were available at the $20^{\text {th }}$ Army of the Republic of Vietnam, ARVN, (South Vietnam) Ordnance Storage Depot, Saigon, and the $511^{\text {th }}$ ARVN Storage Depot, Da Nang [18];

- There was an extensively documented scientific history available on the safety of using 2,4-D, 2,4,5-T and cacodylic acid. As early as 1953, the two phenoxy herbicides were considered "essentially harmless" with only a moderate toxicity to mammals. In 1967, a major report published by Midwest Research Institute, Kansas City, Kansas, on the safety and ecological consequences of the repeated use of tactical herbicides in Vietnam concluded: (1) the direct toxicity hazard to people and animals on the ground is nearly nonexistent; (2) food produced from land treated with these herbicides will not be poisonous or significantly altered in nutritional quality; (3) toxic residues of these herbicides will not accumulate in the fish and meat to the point where man will be poisoned by them; and, (4) the primary ecological change is the destruction of vegetation and the resulting ecological succession in the replacement of this vegetation [19]; and,

- Perhaps equally importantly, by late 1967 the commercial formulations of 2,4,5-T herbicide were no longer available to be purchased in the United States. By FY-1968, the demand for and the use of Agent Orange outstripped the ability of the US Department of Defense to purchase it. As a consequence, the US Government directed that all chemical companies that manufactured 2,4,5-T herbicide must provide that herbicide for the production of Agent Orange. Hence, if 2,4,5-T was going to be used for vegetation control on the DMZ in 1968, it would have to be formulated with 2,4-D as Agent Orange [20].

\section{The Procurement of the Tactical Herbicides}

Based upon the approval of the Secretaries of State and Defense in the United States and the Government of Korea, the following message dated 17 Feb 68 was sent from the Chief of Staff of the United States Army to the Air Force Logistics Command (San Antonio Air Material Area, SAAMA); to the Commander, US Military Assistance Command, Vietnam (COMUSMACV); and to the $1^{\text {st }}$ Logistics Command at Tan Son Nhut, Vietnam:

"Request following herbicides be released to the US Army from RVN Stocks: FSC 6840-926-9094Herbicide Blue, 610 EA 55 gal drums; FSC 6840-926-9095-Herbicide Orange, 350 EA 55 gal drums. Army will arrange transportation to and arrival in Korea not later than 20 March 1968" [21].

On 12 March 1968, the following message was sent from COMUSMACV to the Commander of the United States Eighth Army (GCUSAEIGHT), Seoul, Korea:

"Direct transfer of following herbicides to the US Army from Saigon RVN Stocks and Subsequent Movement to Korea with a Delivery Date of 20 March 1968: 610 Drums of Herbicide Blue, 350 Drums of Herbicide Orange. Herbicide specified above loaded aboard SS Joplin Victory at Saigon on 9 March 1968. SS Joplin Victory, Voyage Number F8105B, Expected Time of Departure, Saigon 14 March with Expected Time of Arrival Inchon Korea 20 March 1968" [21].

The subsequent message was sent from GCUSAEIGHT to COMUSMACV on 10 April 1968 verifying:

"Information requested is as follows: SS Joplin Victory arrived at Inchon, Korea at 1300 hours, 20 March $1968 "[22]$.

The record is incomplete as to the movement of the tactical herbicides from Inchon Harbor on 20 March 1968 until their arrival at the FROKA units on the DMZ on 10 April 1968 [6, 23]. However, in 
Vietnam, Agent Orange drums were off-loaded directly from the cargo vessels at the Port of Saigon or the Port of Da Nang into semi-trailers. Each trailer held 48 drums and they were placed upright and transported to the RANCH HAND bases. This generally required appropriate coordination of vehicles, authorization for transport, the labor arrangements for the handling of the drums, and for a required time period of one to two weeks [24].

\section{Deployment of the Herbicides on the DMZ}

Following a series of planning conferences, a comprehensive vegetation control program was developed. On 10 March 1968, the Commander, US Forces in Korea and the Commander, First Republic of Korea Army [FROKA] were authorized to deploy tactical herbicides as part of the vegetation control program in the Korean DMZ [6]. To preclude the possibility of unfavorable propaganda and to ensure that defoliants would be properly employed with a margin of safety, the following constraints were placed upon the vegetation control program: (a) Defoliants were not to be deployed North of the Southern boundary of the DMZ; (b) During application, care was to be taken to ensure that there was neither run-off nor spray drift into areas North of the Southern boundary of the DMZ; (c) Defoliants would not be applied during precipitation or when rain was expected within 12 hours after application; (d) Extreme caution was to be exercised to avoid damage to food crops; (e) Defoliants would not be dispensed from aircraft of any kind; and (f) a Korean Military Assistance Group (KMAG) Representative 52 (a Chemical Corps Officer assigned to this subordinate element of the Eighth US Army) would be physically present whenever defoliants were deployed [6]. By 20 March 1968, the first herbicide (Monuron) and equipment arrived in country from the United States. On 31 March, implementation of the Vegetation Control Program CY 68 was ordered to begin on or about 15 April 1968. As previously noted, on 10 April 1968 supplies of Agent Orange and Agent Blue were on-hand in forward locations near the DMZ [25]. However, the actual numbers of drums shipped from Saigon and arriving on the DMZ were 380 drums of Agent Orange and 625 drums of Agent Blue.

No records were found in the archival searches that provided an explanation for why the shipping invoice and the receiving receipt had different numbers of drums. However, this difference in the number of drums of Agent Orange and Agent Blue may be resolved by examining the number of drums sent to the Port of Saigon from the Port of Mobile on 5 January 1968 (it took approximately 50 days for the herbicide to be transported to the Port of Saigon). Procurement Records obtained from one of the Chemical Companies that produced tactical herbicides indicated that pallets containing 380 drums of Agent Orange were shipped to Saigon from the Port of Mobile on the 5 January 1968 date [26]. It was also possible that the numbers were based on the number of drums per transport pallet. Another alternative is that the Commander, US Military Assistance Command, Vietnam wanted to ensure that sufficient herbicide was available recognizing that the handling of the drums could result in damaged and leaking drums, although the projected loss of damage was less than $1 \%$ [24].

\section{Conducting the DMZ Spray Operations, 15 April -15 July 1968}

Soldiers from the FROKA were responsible for the task of applying the herbicides, and for managing the entire project. Monuron (UROX 22) was spread by hand or mechanical broadcast beginning on 15 April 1968 and ending 28 April 1968. Approximately 7,800 drums (180,400 kg) of palletized herbicide were applied on 630 hectares or at a rate of $285 \mathrm{~kg} / \mathrm{ha}$ [27].

Applications of the tactical herbicides Agent Orange and Agent Blue began on 15 May 1968 upon the emergence of foliage, and terminated on 15 July 1968, The Orange herbicide was mixed with diesel oil at a ratio of 11 liters of Orange to 190 liters of diesel, i.e., diesel oil is both a solvent and a desiccant. EUSA furnished 7,000 drums of diesel oil for the mixing with the Orange herbicide [6]. Since many application areas selected for spraying with Orange were relatively inaccessible for use of the modified M8A2 Decontamination Trailer, 22 liquid defoliant spray sets were employed. These units were insecticide sprayers commonly used in Engineer Entomological Services and consisted of a portable lightweight hypro-type pump with a standard gasoline engine [6].

The Republic of Korea Army also had available ten M106 "Mitey Mite" dispensers that were used to supplement liquid spray capabilities. The M106 was a commercial, backpack sprayer that consisted of a 
compact two-cycle gasoline engine that dispersed the herbicide through a $1.8 \mathrm{~m}$ hose. The tank contained 11 liters of liquid. The modified M8A2 Decontamination Trailers were used for spraying both Orange and Blue. The unit consisted of a 760-liter capacity tank and a 25 HP GED pump mounted on a $1 \frac{1}{2}$ ton trailer. A single hose reel allowed the operator to move approximately 15 meters from the trailer and direct a liquid spray through the Adjustable Beam-type spray gun at a rate of 75 liters per minute.

Approximately 380 drums of Orange (79,040 liters) were to be applied on approximately 2,820 hectares. Agent Blue was to be applied as a liquid spray mixed with water also at a ratio of approximately 11 liters of herbicide to 190 liters of water. Approximately 625 drums of Blue $(130,000$ liters) were to be applied on approximately 4,660 hectares. All applications were done by ground-based spray systems. The use of masks and handling precautions were mandatory.

The Buckner report noted that 3,345 FROKA soldiers were involved in the actual spray operations. No US military personnel were used to spray the tactical herbicides, or were involved in any of the spray operations, e.g., mixing of the herbicides and diluents. Only one US military person (a Chemical Corps Officer, LTC Julian Buckner) monitored and reported on the activities of the ROKA Forces. And, as noted, the only year that the tactical herbicides were sprayed was 1968 [28].

\section{The FROKA Had Responsibility for the Spraying on the DMZ}

In 1967 (and subsequently in 1969) members of the EUSA did participate in herbicide spray operations on the Korean DMZ. In both 1967 and 1969 commercial herbicides were procured for the operation. Under the Department of Defense's Armed Forces Pest Control Board (AFPCB, now the Pest Management Board, AFPMB), the selection and acquisition of pesticides (including herbicides) for use by DOD military installations had to be approved by the AFPCB and be under the direction of the Installation Civil Engineer and the Command Entomologist [5]. In addition, any pesticide used must have regulatory approval of both the US Department of Agriculture, USDA (now the Environmental Protection Agency) and the host country regulatory program [29]. The confirmation of this requirement was noted in a Report of a Staff Visit to Osan Air Base, Korea in December 1967 by a Civil Engineering Representative (the Command Agronomist) from the Headquarters of the Pacific Air Force. The Agronomist noted that the lush vegetation growing in and around the perimeter fence at Osan AB provided excellent cover for the entrenched and hiding of infiltrators. He recommended that 2,2Dichlorpropionic Acid (Dowpon) and 2-chloro-4,6-bis(ethylamino)-S-Triazine (Simazine) be applied [30]. Both herbicides had USDA Registration and were approved by the AFPCB and by the Korean Ministry of Agriculture, Forestry and Fisheries.

By Department of Defense Directive, the acquisition and spraying of Tactical Herbicides could only be done by the US Army Chemical Corps and the Air Force RANCH HAND program. Tactical herbicides did not come under regulatory review, nor could they be purchased by the Base Civil Engineer [1]. Indeed, the 1970 list of approved pesticides by the Armed Forces Pest Control Board noted that Agents Orange, White and Blue were available ONLY for tactical purposes and NOT for base type pest control [31]. Thus, in 1968 Agent Orange and Agent Blue could not be sprayed by members of the EUSA. The FROKA forces were not under the same Directive and thus the spraying of tactical herbicides on the DMZ was a Korean Military Project, by agreement of the Korean and United States Governments. From the beginning, the ROK assumed full responsibility for the entire on-site operation of organizing and spraying the defoliants. Although LTC Buckner was an observer for the Operation, he stated in his report that: "The FROKA have shown that they have the technical competence and capability to conduct defoliation operations on a massive scale" [6].

\section{Tactical Herbicides Used Only in 1968}

In the latter part of 1968, significant controversy began to surround the use of Agent Orange in Vietnam. The assessment of the Midwest Research Institute Report in 1967 did not dampen the concerns of scientists [19]. In July 1968, the American Association for the Advancement of Science and the National Academy of Sciences issued statements noting that many questions about the ecological effects of tactical herbicides in Vietnam remained unanswered and recommended an international field 
study under the sponsorship of the United Nations be undertaken to analyze the long-range effects of the herbicides on Vietnam's ecology. These controversies surrounding Agent Orange in Southeast Asia resulted in a significant restriction for its use in late 1968, and all uses terminated in April 1970 [32]. The controversy also had the immediate effect in Korea of influencing the decision that tactical herbicides would not be used in 1969. Indeed, records confirmed that tactical herbicides were only used in 1968 and that alternatives would be selected for use in 1969.

Message from CG USAEIGHT to the CINCPAC (Commander in Chief, Pacific Air Forces), dated 20 September 1969 included the statement:

"Request this Headquarters be advised of the possibility of soil applied herbicides, excess in $R V N$, be furnished this Command at no cost to plan continuation of Vegetation Control Program to begin 15 April 1969" [33].

In a subsequent message from COMUSMACV to CG US Eighth Army:

"Soil sterilant TELVAR (MONURON), FSN 6840-514-0644 on hand and excess in $R V N$ is approximately 2,000 Fiber Drums, 160 pounds each, which is sufficient quantity to treat approximately 1,600 acres. This amount can be provided USAEIGHT on non-reimbursable basis. Recommend shipping instructions be provided directly to CG, III MAF, Da Nang, RVN" [34].

An additional confirmation was a MEMORANDUM FOR RECORD prepared in October 1968 by the Office of the Senior Chemical Advisor, US Army Advisory Group, Korea. The Memorandum described small field tests conducted at the DMZ in August and September 1968 that had been recommended by the Plant Sciences Laboratory, Fort Detrick, Maryland to test and evaluate different Monuron formulations and the soil-applied commercial herbicide Bromacil, HYVAR-XL. Thus in 1969, the plan was to apply both Monuron and Bromacil [35].

\section{Findings and Conclusion: The Vegetation Control Plan}

The FROKA and EUSA in the initial planning had proposed to treat 8,110 ha, but in reality the FROKA personnel were only able to treat 7,330 ha, indicating that all of the Orange, Blue and Monuron that had been obtained were depleted. Thus, there was apparently no surplus Orange or Blue to be sent to Camp Carroll. More importantly, all of the Blue and Agent Orange drums became the property of the FROKA, and were rinsed with water or diesel fuel, respectively, and capped [6]. No records were found on the ultimate disposition of the empty herbicide drums by FROKA. The 7,600 fiber drums that had contained the Monuron were burned onsite after they were emptied [6]. The disposal of the 7,000 drums that had contained diesel fuel also presumably became the responsibility of the FROKA, since there were no records in the Archives that any empty drums were sent to the Eighth US Army Materiel Center.

An additional confirmation that no surplus Agent Orange was present in Korea came from Joint Messages and documents of Operation PACER IVY, the Operation responsible for the removal of the remaining stocks of Agent Orange in Vietnam. One of the messages from PACAF, dated 13 October 1971 to all units in Southeast Asia pertained to the consolidation and processing of all Agent Orange stocks for removal from Vietnam or elsewhere to Johnston Island [24]. There were no stocks identified from Korea, thus supporting the conclusion that there were no excess stocks remaining in storage after application on the Korean DMZ. This continued to confirm that the only Agent Orange stocks in Korea were those delivered to the Port of Inchon on 20 March 1968.

Because of Directives 5154.12 and 4150.7, the Department of Defense gave the Armed Forces Pest Control Board/Armed Forces Pest Management Board the authority to set pest management policy "applicable for all Department of Defense pest management activities in any unit, at any time, in any place, even when conducted by contract operations." The significance of these Directives is that any herbicides used after 1961 on the Department of Defense's more than 600 world-wide installations had to be approved by the Board, and had to meet USDA's regulatory requirements, and all the requirements of FIFRA [36]. As previously noted the exception to these Directives was the development of the "tactical herbicides" sprayed in combat military operations in Vietnam, or as noted by the US and Korean Governments' approval as used adjacent to the Demilitarized Zone in 1968. This requirement also meant that Agent Orange or any tactical herbicide could not be sprayed in Korea by base personnel or their contractors at US Military Installations or disposed of in a routine manner. In addition, the 
AFPCB and the Department of Army, including EUSA, had strict guidelines on the handling and disposal of pesticides and pesticide containers, especially on large quantities of hazardous materials [37, 38]. It was noted in the August 1972 report at that time, the US Army's Environmental Engineering Research Unit, Edgewood Arsenal: "The disposal of the Department of the Army's surplus pesticides of all types present serious problems. Significant among the various types of pesticides are large quantities of organochlorine insecticides and phenoxy acid herbicides. Recommendations are made...for phenoxy acid herbicides, including methods for incineration and for secondary disposal of ash and scrubbing liquids... and disposition in chemically or biologically active soils [39].

Another finding and conclusion of the spray program involved the effectiveness of the tactical herbicides on the DMZ and was described by Buckner as follows:

"The effect of Agents Blue and Orange were negated by regrowth of the vegetation in those areas that defoliation was not followed up by controlled burning. The application of these agents in areas other than the DMZ fence trace was of doubtful value. In addition, the drenching of vegetation with Agent Orange/oil mixture and use of Orange on grassy areas were a waste of time and effort" [6].

Buckner also realized that the real failure for the significant re-growth of vegetation in the case of Agents Orange and Blue was that the dilution, mixing, and liquid spray reduced the overall effectiveness of vegetation control [6]. The herbicides 2,4-D and 2,4,5-T were commercially available and approved by the AFPCB as "Brush Killer", and it was formulated as the low volatile esters of 2,4-D \& 2,4,5-T. Typically, "Brush Killer" was aerially applied at the rate $4.48 \mathrm{~kg}$ active ingredient per hectare, ai/ha (active ingredient/hectare) [40]. Agent Orange was formulated as the concentrated high volatile esters and was applied aerially in Vietnam at the rate of $28 \mathrm{~kg} / \mathrm{ha}$. The recommendation for applications of Agent Orange on the DMZ was to dilute the Orange by pouring 11 liters of the Orange into 197 liters of diesel fuel, which meant that although the spray was diluted for the sprayer, the total amount applied by drenching a hectare of vegetation was similar to Vietnam, i.e., $82,460 \mathrm{~kg}$ ai applied to 2,820 ha or approximately $29 \mathrm{~kg}$ ai/ha. However, much of the effects on the vegetation did not occur as a consequence of the herbicides but rather as a consequence of the diesel fuel drying out the leaves before the herbicide could penetrate to the roots [6]. In Vietnam, Agent Orange was not formulated with diesel fuel, but was applied as the concentrate [24].

After a thorough examination of the records found in the United States National Archives and a critical assessment of the Buckner report and supporting documents, the following conclusion can be made: The allegations noted in the introduction were simply not based on military directives or the facts found within the historical records; namely, there was never any Agent Orange sent to or buried at Camp Carroll, or sprayed elsewhere in South Korea, except at the DMZ in 1968.

\section{A Brief Review of the Science}

Newton and Norris reported on a study of human exposures to 2,4,5-T and TCDD through dermal contact, research and monitoring of field applications and water quality since 1963, and studies of wildlife contamination occurring with field use of herbicides in the Oregon Coast Ranges of the United States. They noted the following:

"The human health risk from short-term exposure to a chemical (e.g., 2,4,5-T) is a function of the level, duration, and frequency of contact dose with the chemical, compared with the maximum level, duration, and frequency of exposure producing no symptoms. The frequency of exposure producing no symptoms is estimated from animal tests in the absence of controlled human experiments. We are operating under the general assumption that exposure has no health implications unless the chemical enters the body where physiological processes must deal with it" [41].

One of the studies by Newton and Norris involved the measurement of exposure of an individual that was more than 200 meters downwind of the spraying of 2,4,5-T. They estimated that during the first week after application, the resident received a total dose of $0.0019 \mathrm{mg} 2,4,5-\mathrm{T} / \mathrm{kg}$ for a $70-\mathrm{kg}$ adult, and a total dose of $1.9 \times 10^{-11} \mathrm{mg} \mathrm{TCDD} / \mathrm{kg}$. Nearly half the total exposure occurred on day 1 of spraying (indicating the rapid half-life of $2,4,5-\mathrm{T}$ ). The acute no-effect estimates were $40 \mathrm{mg} / \mathrm{kg}$ for $2,4,5-\mathrm{T}$ and $0.0001 \mathrm{mg} / \mathrm{kg}$ for TCDD. Exposure of applicators whose soaked clothing, or who otherwise came in continuous contact with a spray mixture (directly sprayed with $2.2 \mathrm{~kg} /$ ha eight times per day) had a net dose of $0.049 \mathrm{mg} 2,4,5-\mathrm{T} / \mathrm{kg}$ (70-kg applicators) [41]. 
Newton and Norris also found in their monitoring programs that, with few exceptions, herbicide found in stream water was the result of direct application to the water. The low solubility of TCDD suggested that there would be a greater differential adsorption of TCDD on sediments in preference to 2,4,5-T, and that the actual levels would be lower than calculated [41].

Lavy et al have also conducted numerous studies of phenoxy herbicide applicators. The results of one six-day study of both a backpack crew and from a crew spraying from a tractor showed that the degree of exposure was related to the worker's job [42]. External dermal and respiratory exposures were measured and total intake of 2,4,5-T was determined from total urine collected from each worker for a 6 -day period. The greatest amounts of exposure to 2,4,5-T were detected in mixers of the compounds and least amount in the sprayers. The exposure to 2,4,5-T averaged $0.0005,0.586$, and $0.033 \mathrm{mg} / \mathrm{kg}$ body weight for inhalation, patch, and internal measurements, respectively. These measurements indicated that the worker excreting the highest amount of 2,4,5-T (the mixer) received exposure levels significantly below those toxic to laboratory animals [42].

Smith et al conducted a study of the blood serum levels of TCDD in a group of nine professional 2,4,5-T applicators in New Zealand [43]. The nine applicators had sprayed 2,4,5-T for a range of 83-372 months. They measured the blood serum levels of polychlorinated dibenzo- $p$-dioxins and dibenzofurans, which were substituted with chlorine at the 2,3,7,8 position, in the nine applicators and in a matched group of nine control subjects. The average serum level of TCDD for applicators was almost 10 times that for the matched control subjects, while the average levels of all other congeners and isomers measured in the two groups did not differ substantially. They concluded that increased risks of cancer from brief exposure to phenoxy herbicides reported in other countries were probably not attributable to the TCDD that contaminated 2,4,5-T [43].

In 1982, the United States Air Force initiated the Air Force Health Study, a study of the Air Force personnel involved in Operation RANCH HAND - the program responsible for tactical herbicide spraying in Vietnam. The 20-year matched cohort study consisted of independent mortality, morbidity and reproductive health components. An appraisal of the study nearly a decade since the final follow up examination indicated that the results did not provide evidence of disease in the RANCH HAND veterans caused by their elevated levels of exposure to Agent Orange [44].

Finally, the following studies may be relative to the exposure of FROKA soldiers who sprayed Agent Orange on the Korean DMZ in 1968. Studies of the properties of plant surface waxes of the cuticle layer have shown that Agent Orange, including TCDD, would have dried (i.e., be absorbed into the wax layer of the plant cuticle) upon spraying within minutes and could not be physically dislodged. Studies of Agent Orange and the associated TCDD on both leaf and soil surface have demonstrated that photolysis by sunlight would have rapidly decreased the concentration of TCDD, and this process continued in the shade. Studies of 'dislodgeable foliar residues' (DFR, the fraction of substance that is available for cutaneous uptake from the plant leaves) showed that only $8 \%$ of the DFR was present 1 hour after application. This dropped to $1 \%$ of the total 24 hours after application. Studies with human volunteers confirmed that after 2 hours of saturated contact with bare skin, only $0.15-0.46 \%$ of $2,4,5$-T entered the body and was eliminated in the urine [45].

\section{Conclusion}

After a thorough review of the science, the following conclusion can be made: The prospect of any significant exposure and subsequent health impact to TCDD from Agent Orange in the FROKA soldiers or nearby residents seems unlikely in light of the environmental dissipation of TCDD, little bioavailability, and the properties of the herbicides and circumstances of application that occurred.

Acknowledgement. This article was based on a contract from Oak Ridge Associated University through their program of supporting scientific research via Oak Ridge Institute for Science and Education (ORISE)1 July 2011 - 1 December 2011. Dr. Alvin L. Young was hired as a Professor of Toxicology and Mr. Kristian L. Young as a Researcher supporting the Project. The Project was to provide expert consultation and a report to the Eighth United States Army (EUSA) in Korea on allegations that the United States had sprayed Agent Orange and buried large quantities of Agent Orange near Camp Carroll in Southern Korea. A 10-day trip was taken to South Korea and meetings 
were held with EUSA Command Staff, and with the Korean Ministry of National Defense and Ministry of the Environment. Special thanks to EUSA Staff and the Staffs of the two Ministries. Thanks to the Staff of the United States National Archives for their assistance in finding documents related to the project. We wish to acknowledge ORISE for the financial support and clearances needed to complete this project.

\section{References}

1. A. L. Young, "The History, Use, Disposition, and Environmental Fate of Agent Orange. Springer, 2009.

2. A. Rowland and Y.K Chang, S. Korea probes allegations of buried chemicals at ex-U.S. base, Stars and Stripes, May 25, 2011.

3. Nam Jong-young, Allegations expand to civilian mobilization for DMZ dump. Yonhap News, May 26, 2011.

4. G. Kirk and C. Ahn, Agent Orange in Korea, Foreign Policy in Focus, Institute for Policy Studies, Washington, DC, July 7, 2011.

5. A. L. Young, The History of the US Department of Defense Programs for the Testing, Evaluation, and Storage of Tactical Herbicides, 2006. Available from the Defense Technical Information Center (www.dtic.mil ), accession number: ADA534602.

6. J. E. Buckner, Final Report, Vegetation Control Plan CY 68, Prepared for the Combat Developments Command, Chemical-Biological-Radiological Agency, Fort McClellan, Alabama, June 2, 1969.

7. S. R. Larson and J. L. Collins, Jr., The Republic of Korea, Chapter VI: IN: Vietnam Studies: Allied Participation in Vietnam, Department of the Army, Washington DC, 1975.pp 131-134.

8. R. P. Fox, Air Base Defense in the Republic of Vietnam, 1961-1973, Office of Air Force History, Washington, DC, 1979, pp 74-75.

9. Kyong-hyun Kim, Song-ryong Chong, and Un-ho Lee, Vietnam War and Agent Orange, Vol 1, English Translation, Medical Bureau of the Korean Armed Forces, Ministry of National Defense, Korea, 1978.

10.J. Park, Scientific Evaluation of the Results of the Third Epidemiological Study on Defoliants. The Korean Society for Preventive Medicine commissioned by the Minister of Patriots \& Veterans Affairs, December 2006.

11.N. E. Sarantakes, The Quiet War: Combat Operations Along the Korean Demilitarized Zone, 1966 -1969, The Journal of Military History no. 64 pp 439-458. April 2000.

12.Joint Message, Request for Technical Assistance, Howard E. Kreidler, Colonel, USAF, Directorate of Operations, HQ, USAF to TAC and PACAF, 6 November 1963. Obtained from the Historical Records of the Eighth United States Army, Series 338, Washington National Records Center, Suitland, MD.

13.EUSA Study, Analysis of DMZ and Contiguous Operations: The Rice Report, Historical Records of the Eighth US Army, 1966. Extracted by the US Army \& Joint Services Records Research Center for the Department of Veterans Affairs, Springfield, VA.

14.HQ EUSA Ltr, Special Analysis of the DMZ and Contiguous Operations, Historical Records of the Eighth US Army, 1967. Extracted by the US Army \& Joint Services Records Research Center for the Department of Veterans Affairs, Springfield, VA.

15.Korean Ministry of Patriots \& Veterans Affairs. Regulations Regarding the Scope of Area Adjacent to Southern Limit Line Where Defoliants Were Used. 1969. The "Area Adjacent to Southern Limit Line" was determined pursuant to the provisions of Article 2 of the Korean Ministry of Patriots \& Veterans Affairs The area refers to (1) the area 100 meters away from the north or south of the Southern Limit Line, (2) the area adjacent to observation posts, command posts and other important military installations built near the Area Adjacent to the Southern Limit Line, and (3) the area 30 meters away from the right or left side of the tactical road near iron railings (or fences) installed near the Southern Limit Line.

16.J. V. Smith, RADM, Senior Member UN CMACN confirmed that the United Nations Command was aware that the FROKA was preparing to use defoliants on the DMZ, 8th Army Chronology, published by the Staff Historian Office, Eighth United States Army, APO 96301.

17. Yearbook of Agriculture and Forestry Statistics, Consumption Trends of Herbicides by Group in Korea, Published by the Ministry for Food, Agriculture, Forestry, and Fisheries, Seoul, Korea, 2010-2011.

18.D. A. Craig, Use of Herbicides in Southeast Asia, Directorate of San Antonio Energy Management, San Antonio Air Materiel Center (SAAMA), Kelly AFB, TX, USA, 1975. 
19.W. B. House, L. H. Goodson, H. M. Galberry, and K. W. Docktor, Assessment of Ecological Effects of Extensive or Repeated Use of Herbicides, Midwest Research Institute, Kansas City, MO, USA, 1967, http://www.dtic.mil/get-tr-doc/pdf?AD=0824314.

20.Joint Message, Total National Production of Butyl Esters of 2,4,5-T Restricted for the SEA Defoliation Program, Commander of the Defense Supply Center, Richmond, VA to Army Logistical and Support Commands, 16 December 1967.

21. The authorization process required that a message be sent from SAAMA to COMUSMACV, RVN. This was accomplished on 17 Feb 68. COMUSMACV notified Commander, EUSA, Korea of the transfer of the required inventory, and the Air Force Chief of Staff finalized the transfer and provided a fund citation, 20 March 1968. These messages were in the United States National Archives at College Park, MD and were part of the records from the United States Air Force Judge Advocate.

22. This message was also in the National Archives at College Park, Maryland, and was part of the records from the United States Air Force Judge Advocate Records, message dated 20 March 1968.

23.This message was also from the United States Air Force Judge Advocate Records, message dated 20 March 1968.

24.A. L. Young, Agent Orange: A History of Its Use, Disposition, and Environmental Fate, Chapter 3, Figure 3.11and accompanying text, 2008, http://www.dtic.mil/dtic/tr/fulltext/u2/a534602.pdf.

25.J. E. Buckner, Final Report, Vegetation Control Plan CY 68, 8-10. It should be noted that the allegation by US Korean Veterans that the two tactical herbicides were first sent to Camp Carroll is not supported by the messages, the required coordination time, or the on-site observations at the Korean DMZ.

26.Procurement and shipping information was provided to the Multi-District Litigation in RE: Agent Orange Product Liability Litigation, Case MDL 381, closed May 1985. Records are archived at the Washington National Records Center, Suitland, MD, USA.

27.J. E. Buckner, Final Report, Vegetation Control Plan CY 68, 7-8. Both Agents Orange and Blue were sprayed on the vegetation until saturated. This ensured complete coverage of the vegetation.

28.T. Sypko, Korean DMZ Vets \& Agent Orange, VFW Magazine, January 2004. Sypko incorrectly noted that Agent Orange was used from April 1968 through July 1969. This incorrect information was used in the determination by the US Department of Veterans Affairs in decisions on presumptive compensation.

29.Editor Submission, USDA Moves to Tighten Pesticide Labeling Regulations, Agricultural Chemicals, October 1963, no. 38, pp 125-128. The revision of the regulations also required the use of appropriate foreign language version of the label, in addition to the English version.

30.F. R. Gross, Command Agronomist, Report of Staff Visit to Japan and Korea, Director of Operations \& Maintenance, DCS/Civil Engineering, Headquarters Pacific Air Force, 8 January 1968

31.J. F. Adams, Pesticides and Pest Control Equipment: Information Concerning. Report NMFRL 3900.3, Naval Medical Field Research Laboratory, Camp LeJeune, NC, USA, 1 August 1970.

32.G. Reggiani, Historical overview of the controversy surrounding Agent Orange, Chapter 3 in A. L. Young and G. Reggiani, Agent Orange and Its Associated Dioxin: Assessment of a Controversy, Elsevier 1988. On 15 April 1970, the US Departments of Health, Education, and Welfare, Interior, Agriculture and Defense announced the immediate suspension of the major uses of 2,4,5-T. At the direction of the Department of Defense, RANCH HAND aircraft flew their last mission involving Agent Orange on 16 April 1970.

33.Joint Message, Subject: Vegetation Control. The message also noted that personnel from Fort Detrick were evaluating soil applied herbicides. R. O Radke and R. A. Darrow, The Lateral and Vertical Movement of Four Herbicides Applied to a Grassland Soil, Technical Memorandum 212, Department of the Army, Fort Detrick, October 1970 .

34.Joint Message, Subject Herbicides. Monuron was routinely used in Vietnam as a soil sterilant for use around military facilities and fence lines. It was approved by Armed Forces Pest Management Board for use on US military bases.

35.E. A. Lewis, Lt, US Army Chemical Corps, Summary of 1968 Vegetation Control Tests, US Army Advisory Group, Korea, and Office of the Senior Chemical Advisor, October 1968.

36.B. F. Eldridge, AFPCB Recommended Statement on Use and Disposition of Pesticides. Information Service Division, Armed Forces Pest Management Board, US Army Garrison-Forest Glen, 2460 Linden Lane, Bldg 172, Silver Spring, MD1971. 
37.Department of Defense Instruction, Pest Control Operations at Military Installations. Directive 4150.7, The Office of the Assistant Secretary of Defense for Installations and Logistics, Washington DC, 23 July 1964.

38.USFK Regulation 700-17, Use of Herbicides in the Republic of Korea. This regulation was initially issued by HQ, United States Forces Korea, 12 March 1984.

39.T.A. Miller, Problem Definition Study: Evaluation of Health and Hygiene Effects of the Disposal of Pesticides and Pesticide Containers. US Army Medical Environmental Engineering Research Unit, Edgewood Arsenal, MD, August 1972, http://www.dtic.mil/citations/AD0757603.

40.R. W. Bovey, Uses of Phenoxy Herbicides and their methods of application, Chapter 3, IN: R. W. Bovey and A. L. Young, The Science of 2,4,5-T and Associated Phenoxy Herbicides, John Wiley \& Sons, New York, 1980.

41.M. Newton and L. A. Norris, Potential exposure of humans to 2,4,5-T and TCDD in the Oregon coast ranges, Fundamental and applied toxicology no. 4, pp 1:339-346, 1981.

42.T. L. Lavy, J. S. Shepard, and J. D. Mattice, Exposure Measurements of Applicators Spraying (2,4,5Trichlorophenoxy) acetic Acid in the Forest, Journal of agriculture and food chemistry, no. 28, pp 626-630, 1980. The oral LD50 for 2,4,5-T was $300 \mathrm{mg} / \mathrm{kg}$ for rats and $100 \mathrm{mg} / \mathrm{kg}$ for dogs. In a chronic 2-year feeding study, the no-effect level for 2,4,5- $\mathrm{T}$ was at a dosage rate of $3 \mathrm{mg} / \mathrm{kg}$ per day. The hazard to wildlife from $2,4,5$ - $\mathrm{T}$ at used and recommended rates was negligible.

43.A. H. Smith, D. G. Patterson, Jr., M. L. Warner, R. MacKenzie, and L. L. Needham, Serum 2,3,7,8Tetrachlorodibenzo-p-dioxin Levels of New Zealand Pesticide Applicators and Their Implication for Cancer Hypothesis, Journal of the National Cancer Institute, no. 84 (2), pp 104-108. This lack of evidence does not mean that TCDD does not cause cancer, but the current science does not establish a cause and effect relationship.

44.P. A. Buffler, M. E. Ginevan, J. S. Mandel, and D. K. Watkins, The Air Force Health Study: An Epidemiologic Retrospective, Annals of Epidemiology no. 21 (9), pp 673-687, 2011.

45.A. L. Young, J. P. Giesy, P. D. Jones, and M. Newton, Environmental Fate and Bioavailability of Agent Orange and Its Associated Dioxin During the Vietnam War, Environmental Science \& Pollution Research, no. 11 (6) pp 359-370, 2004. 